\title{
GLOBAL ETHICS
}

\section{The possibility of a universal declaration of biomedical ethics}

\section{K M Hedayat}

J Med Ethics 2007;33:17-20. doi: 10.1136/jme.2006.016170

Statements on issues in biomedical ethics, purporting to represent international interests, have been put forth by numerous groups. Most of these groups are composed of thinkers in the tradition of European secularism, and do not take into account the values of other ethical systems. One fifth of the world's population is accounted for by Islam, which is a universal religion, with more than 1400 years of scholarship. Although many values are held in common by secular ethical systems and Islam, their inferences are different. The question, "Is it possible to derive a truly universal declaration of biomedical ethics?" is discussed here by examining the value and extent of personal autonomy in Western and Islamic biomedical ethical constructs. These constructs are then tested vis-à-vis the issue of abortion. It is concluded that having a universal declaration of biomedical ethics in practice is not possible, although there are many conceptual similarities and agreements between secular and Islamic value systems, unless a radical paradigm shift occurs in segments of the world's deliberative bodies. The appellation "universal" should not be used on deliberative statements unless the ethical values of all major schools of thought are satisfied.

\section{Correspondence to: Kamyar M Hedayat Pediatric Intensive Care, Integrative Medicine, Sutton Children's Hospital, Christus Health Systems, Shreveport, LA 71101 , USA; kamyar.hedayat@ christushealth.org}

Received 31 January 2006 Revised 9 March 2006 Accepted 13 March 2006
$\mathrm{S}$ everal well-known international medical and biomedical bodies, such as the World Medical Association (WMA) and the Unesco's International Bioethics Committee, have established universal declarations of rights on various aspects of clinical practice. ${ }^{12}$ These declarations were initiated and authored primarily by secular thinkers, in the European tradition (although not necessarily from Europe). These groups represent only a minority of the world's population. Muslims represent $20 \%$ of the world's population and $30 \%$ (58/191) of the world's countries.

The WMA's membership includes nine Muslim countries. ${ }^{\text {ii Unesco's International Bioethics }}$ Committee, composed of experts from 36 countries, includes six representatives from Muslim countries-16\% of the membership body.

Three of the six countries, Lebanon, Syria and Turkey, however, have secular or socialist constitution.

Hence the need for a broader, more inclusive and truly "universal" framework for such a declaration of rights.

Islam has a highly developed legal code, the shar'iah, as well as a distinguished intellectual history of philosophy, jurisprudence and ethics. ${ }^{3-5}$ With limited exceptions, such as the Islamic Medical Code of Ethics, Muslim organisations have not been active in drafting declarations of biomedical ethics. ${ }^{6}$ Nonetheless, there are many points of confluence between the rights and principles observed in Islamic jurisprudence, occidental philosophy and universal bills of rights such as the WMA. ${ }^{1}$ Points of overlap include principles such as the inherent freedom of mankind, autonomy, patients' right to honest information and the inviolability of the doctor-patient relationship. ${ }^{5}$

Even where there appears to be agreement in principle, the conclusions reached are different. This is partly because of differing assumptions and foundational beliefs as points of induction. In addition, Islamic jurisprudence allows for consideration of local customs and the specific needs of the petitioner (personal, familial and psychological), leading to situational ethics. ${ }^{5}$

This article seeks to determine whether a truly universal code of bioethics is possible, by examining the commonly held belief in personal autonomy. Autonomy over bodily functions is further examined in the light of the controversial practice of elective abortion, comparing secular and Islamic approaches. If controversial issues cannot be resolved, the feasibility of a truly universal code of ethics would be called into question.

\section{DISCUSSION}

Freedom and autonomy in general and the role of reason

Western philosophy and clinical ethics are replete with theories of autonomy based on a secular, anthropocentric world-view. This stands in stark contradistinction to the theocentric cosmology posited by Islam. Emmanuel Kant believed that humans were inherently free and hence autonomous. In Kant's view, reason was not the factor that distinguished people as free but was rather a means to understanding that freedom. On this point, Islam agrees. For example, Imam Ali stated, "Truly Adam did not give birth to slaves-male or female-and mankind-all mankind-is free." ${ }^{\prime 7}$ But there the similarity ends.

Abbreviation: WMA, World Medical Association

iThe Organization of Islamic Conferences has 58 member states. The United Nations has 189 member states with two, Switzerland and the Vatican, abstaining from membership.

iihttp://www.wma.net/e/members/list.htm laccessed 18 Apr 2006)

iiihttp://portal.unesco.org/shs/en/ev.php-URL_ID $=2027$ $\& U R L \_D O=D O \_T O P I C \& U R L$ SECTION $=201 . \mathrm{html}$ (accessed 18 Apr 2006). 
Kant goes further than the teachings of Islam would go, implying that because people are free they may make their own laws conforming to their own reasoning and obey only those laws. ${ }^{8}$ This divergence between classical Western philosophy and the tenets of Islam is critical-the essence of Islam, indeed its translation, is "submission". In this case, it is submission to the will (and reason) of God. In Islam, reason is the "pillar of human existence ... Man is perfected through reason and it is this which is a guide, a discriminator, and a key to every success", taught the Prophet Muhammad. ${ }^{9}$ It is because of reason, and aided by it that people know God's laws and their own purpose in life. People are not subject to blind faith in Islam. In clarifying what reason guides one to, the quote continues:

It is through reason that (man) knows who guides him and who misguides him ... he quickly comprehends where he stands, and what is what, which is which, and why he has been sent here in this worldly life, where he is brought from, and where he has to go (i.e., the day of judgement). All this can be secured with the assistance of reason. ${ }^{?}$

\section{Freedom in the self: the body and mind}

According to Islam the body is a vehicle by which the soul is tested to show its mettle and fealty to God. People may clothe and feed their bodies as is suitable. When the body is ill, it suffers, is physiologically damaged and needs maintenance. People have an obligation to seek treatment when they are ill because they are the keepers of the sacred gift that is the body. To the degree that a person's illness endangers only himself or herself and not others, neither Islam nor an Islamic state can compel him or her to seek treatment. If people deny themselves treatment and die, the sin is on them, but in so doing they have exercised their autonomy.

Free will is the medium by which God's test of mankind is executed: "The truth is from your Lord, so let him who please(s) believe, and let him who please(s) disbelieve." $(18: 29)^{10}$ But, to be meaningful, free will must be truly free. Therefore, people are not compelled to do right or wrong, but they must account for their decisions on the Day of Judgement. In this regard, the Prophet Muhammad taught that, "Freedom, in truth, is to be free in all affairs, ${ }^{\prime 11}$ but he also clarified that, "He who frees himself from carnal desires is (truly) free." ${ }^{12}$

Freedom in society: the divine code of ethics (shar'iah) Humans are social by nature and depend on the division of tasks and specialisation of labour among the many to live. Hence, there must be a law by which the conflicting rights and desires of people are regulated lest the social order break down. Prophets are placed among people to pronounce the divine path for both the people and society-namely, the divine code of ethics or shar'iah. Shar'iah inures to the benefit of people in this world and the next by checking carnal desires and selfish impulses, offsetting them by pointing to the individual and the common good. The Prophet Muhammad summed up his entire prophetic mission and earthly goals in these terms: "I came not but to refine human morals (makarim al-akhlaq)."13 Hence, Muslims must regulate their own private affairs and Islamic government public affairs in a manner that adheres to shar'iah-that is, the Qur'anic command: "And from among you there should be a party who invite to good and enjoin what is right and forbid the wrong, and these it is that shall be successful (in this world and the hereafter)." $(3: 104)^{10}$

\section{The application of freedom to the body, mind and society}

It is a common assumption of legal systems, secular and divine, that we cannot dispose of other people's property with impunity. A bailee, one entrusted with the property of another, must maintain the entrusted object or be accountable for its misuse. In Islam, God is the teleological owner of all things because He is the originator of all things. Under Islamic law, a person's ownership of goods is recognised under Islamic law as absolute with regard to the claims of others but relative with regard to the claims of God. If a person purchases a horse, for example, the animal cannot be taken by another person without the consent of the owner and proper remuneration. But the owner of the horse may neither overwork the animal nor deny it shelter, food or water. Shar'iah requires that the earthly owner of the horse take care of it because the heavenly owner, God, has assigned a right to that horse, which should not be denied to it (namely, humane care).

\section{Case in point: elective abortion}

Consider the case of pregnancy. Pregnancy is an unusual physiological situation. It is not an illness, but is sometimes treated like one. The fetus is not solely the property of the mother, as it originated from both its mother and father. The concept of autonomy is put to the test in the case of an elective abortion because the rights of the fetus and its claim to life are challenged by the woman's claim to autonomy over her body.

The rationale for elective abortions is that the pregnant woman may at all time exercise autonomy over the treatment of her body. ${ }^{14}$ Some even deny that the fetus is a separate "patient", 15 even though the fetus has its own circulatory system, respiratory physiology, movements and unique pharmacodynamic and pharmacokinetic responses with respect to medications - all attributes of a living being (and to the point, a patient). ${ }^{16}{ }^{17}$ In its controversial landmark decision in 1973, the US Supreme Court looked at the issue of abortion as one of privacy and not one of autonomy as such. ${ }^{18}$ There, the Court journeyed from the so-called "penumbra of rights" postulated by Justice Goldberg in Griswold $v$ Connecticut, ${ }^{19}$ coming to rest on the proposition that individual autonomy must therefore overshadow contrary religious, moral or social interests-in other words, the Kantian view over the Islamic view.

Yet, the principles enunciated in Griswold and Roe are soundly rejected by over one millennium of Islamic scholarship as well as by common sense. Neither in the Muslim nor nonMuslim world does the so-called right to autonomy that permits elective abortion also empower parents to kill the same infants after birth through neglect or abuse. Do appendages have an independent life outside the body that a fetus is treated as a woman's body but an infant is treated as a person? Why then are those principles retracted when the issue concerns the life of the fetus?

The claim that the fetus falls under the exclusive and unfettered domain of the pregnant woman is rejected in Islam. In the case of elective abortion, the object being removed is not the woman's womb, or a particular ovule, but a growing entity, which is not a priori a part of her body (to use Kant's term), but a separate, growing entity engaged in a symbiotic relationship with her via the placenta. From an Islamic perspective then, the fetus is an independent being, with innate human status.

Human development is viewed in Islam as a continuum and personhood is granted on the basis of parental lineage and the contribution of genetic material. This concept is summed up by this prescient verse from the Qur'an, disclosed to the Prophet Muhammad and pronounced to a medieval population nearly 1400 years before science proved the proposition:

We created you from dust, then from a small seed, then from a clot, then from a lump of flesh, complete in make (because of the genetic programming to take human form $-\mathrm{KMH}$ ) and incomplete (because the soul has not been breathed in to 
make it fully human-KMH), that We may make clear to you; and We cause what We please to stay in the wombs till an appointed time, then We bring you forth as babies, that you may then attain your maturity. $(22: 5)^{10}$

The early fetus-at less than 17-18 weeks of gestation-is not viewed as fully human, but as something humanesque, again, along the continuum of humanness, and nevertheless intrinsically human. The analogy used in classical jurisprudence is that of the seed of a tree. An oak seed is not an oak tree, but came from an oak tree, and, left alone to take root and grow, will become an oak tree. Once the spirit of life, or, the soul, is breathed into the fetus, it is referred to as another creationnamely, a human being:

Then We made the seed a clot, then We made the clot a lump of flesh, then We made (in) the lump of flesh bones, then We clothed the bones with flesh, then We caused it to grow into another creation, so blessed be Allah, the best of the creators. $(23: 14)^{10}$

Compare the above verse with the writings of Singer, who questions the humanness of infants and the mentally retarded because of their lack of self-awareness or articulated desire. ${ }^{20}$ Yet this argument also fails. In Islam, humanness is based on the potentiality of possession of a soul, which occurs in the uterus. Imam al-Baqir explained this point more than 1300 years ago as follows: "The sperm reaches the womb ... (After 4 months of development) God sends two creator angels ... they blow in [to the fetus] the spirit of life and eternity ... ". ${ }^{21}$ In Islam, it is the soul that has eternal life and it is only people who have souls.

Put another way, in the Islamic view of life, humanness is not based on a particular form, the possession of a minimum number of digits or even on the possession of a certain minimum intellectual capacity ("cogito ergo sum"-I think, therefore I am-as Descartes would have us believe). Humanness is innate but not fully expressed at conception. With the presence of a soul, humanness becomes fully manifest. In the situation of a woman who wishes to abort a fetus that does not threaten her health, Islam overrides the woman's autonomy on the basis of another compelling interest-namely, the existence of a defenceless person. Even if the fetus were not considered to be a person with individual rights, and instead were considered to be merely an inanimate extension of the woman's body, the autonomy granted to the woman in Islam would not extend to harming her body. Again, we return to the concept of mankind as a bailee for the gift of the body entrusted to it by God.

In summary, the fetus has a place that is in between animal and human life on the continuum of human development. Metaphysically, the fetus is a full human when the soul enters into it, that being the essential requirement of humanness. With each stage of development, the rights of a fetus increase incrementally. Abortion, however, is still not permissible without a compelling reason before the fourth month of development when the soul enters because the fetus's innate tendency to become human gives it sufficient right to remain unmolested under normal circumstances. ${ }^{22}$ In other words, Islam recognises the fetus to be an independent living entity separate from the woman, endowed with its own rights, which include the right to grow and continue living.

\section{Working towards a universal declaration of ethics}

How then do we reconcile the following statements from international bodies on the one hand, and what Islam declares on the other? Regarding autonomy, the WMA says: "The patient has the right to choose freely and change his/her physician ... Every patient has the right to be cared for by a physician ... without any outside interference. The patient shall always be treated in accordance with his/her best interests."1 So far, nothing in these statements appears to contradict Muslim jurisprudence regarding patients' rights or the claim to autonomy. ${ }^{23}$

As noted above, the WMA declaration speaks of the rights of the patients but not of the people themselves. It is undeniable that the fetus is treated as a distinct patient when there is a plan to carry the pregnancy to term, but is reduced to a private bodily function when there is a desire to electively abort it and hence lacks personhood for the WMA, real or potential. Hence, the WMA's position is both inherently contradictory and in total contradistinction to the Islamic position elaborated above. Sadly, the fact is that even animal welfare laws are better developed to protect small animals than the accord granted to fetuses by the WMA. ${ }^{24}$ Many staunch supporters of animal rights deny that the same arguments ensuring rights based on sentience can be applied to fetuses..$^{25}$ This is no mere oversight or underdeveloped discipline of bioethics-it may fairly be stated that the WMA's position is uniform in its disregard for the life of the fetus in the context of elective abortion. What is more, the WMA's Ottawa declaration on the rights of the child excludes children not yet born. ${ }^{26}$ The fetus, then, although a necessary and universal development for human existence, has no explicitly defined rights under the rubric of a consenting pregnant adult or a minor, according to the WMA.

Even if one denies personhood to an unborn child, it cannot be denied that medically there exists a separate patient within the womb. The Council of Europe in its Convention on human rights and biomedicine considers elective abortion for sex selection to be amoral and prohibited (article 14), but smiles on elective abortions for no particular reason. Presumably the desire of the Council of Europe to prevent sex discrimination before birth is based on a concept of personhood or inherent fetal rights, but fails to extend the same dignity to fetal life due, ironically, to what it perceives to be concerns about the individual rights and autonomy (article 2) of the mother. ${ }^{27}$

\section{CONCLUSIONS}

Muslims and non-Muslims agree that autonomy is a right of mature humans and that the welfare of non-autonomous people should be vigilantly guarded. Because the concept of autonomy is derived by different inferences, its application results in different codes of ethics.

Secular thinkers conclude that humans have a right to autonomy because they are capable, rational beings or because they are inherently free and hence autonomous. Therefore, no one needs to, nor should anyone, make decisions for others when the people themselves are capable of it. In biomedical terms, this means that people are free to do whatever they wish to their bodies, including securing non-therapeutic abortions.

In Islam, autonomy arises from the creation of humanity by the Divine: it is the spark of the Divine that animates all human activity. Yet that freedom is a state given by God to test the resolve of humankind to strive to be better than Angels, as is the calling of a person's highest nature. Because a person's body and soul are created by God and owned by Him in the teleological sense, a person's autonomy should be used in seeking the welfare of the body and the soul. To the degree that a person compromises the welfare of the body but does not harm others, he is free to do as he pleases-subject to the consequences of his actions. The fetus, however, is not merely an appendage within a host, but a living being worthy of divine and hence human, protection, and we cannot simply sweep this fact under the rug of autonomy any more than murder can be 
justified in any other circumstance. Sadly, despite their ostensible recognition of a right to life and human dignity, the secular declarations noted above do not make any provisions for the treatment of a fetus.

Many conceptual points of agreement exist between Muslims and non-Muslims in the arena of biomedical ethics, including the concepts of autonomy, beneficence, justice and nonmalfeasance. Because they are derived by differing inferences-namely, theocentric as against anthropocentric cosmologies, respectively, the applications of these apparently common beliefs disclose important differences and, in the end, a truly universal code of ethics may not be possible in application.

Clinical ethics, like politics, is ultimately a local phenomenon where cultural-and syncretic religious—sensibilities influence the development and application of biomedical ethics. We can consider the role of the Catholic Church in Africa with regard to AIDS ministering and prevention, ${ }^{28}$ and the influence of Muslim scholars with regard to organ donation or cloning. ${ }^{29}$ What is problematic are the declarations from a numerically small but disproportionately influential group of secular thinkers using nomenclature such as universal, where large sections of the world adhere to theocentric ethics, including many Christians and Jews in Western countries.

\section{ACKNOWLEDGEMENTS}

I thank Hasan Askari, MD, PhD, National Institute of Health, and MM Hedayat, Esq for their helpful suggestions regarding Western philosophy and Law, and their stylistic comments.

Competing interests: None.

\section{REFERENCES}

1 World Medical Association. Declaration of Lisbon of the rights of patients, 2005. http://www.wma.net/e/policy/l4.htm (accessed 3 Mar 2006)

2 United Nations Educational, Scientific and Cultural Organization. Universal declaration on bioethics and human rights. 2005. http://portal.unesco.org/shs/ en/file_download.php/

46133elf469le4c6e57566763d474a4dBioethicsDeclaration_EN.pdf (accessed 5 Mar 2006).

3 Nasr SH, Leaman O, eds. History of Islamic philosophy. London: Routledge, 1996: 165-275

4 Baqr al-Sadr, SM. A short history of 'Ilmul Usul. Karachi: Islamic Seminary Publications, http://al-islam.org/usul/ (accessed 18 Apr 2006).

5 Brockopp JE, ed. Islamic ethics of life: abortion, war, and euthanasia. Columbia: University of South Carolina Press, 2003.
6 Anon. The Islamic Code of Medical Ethics. World Med J 1982;29:78-80.

7 Sharif al-Radhi M. Nahjul Balagha: sermons, letters, and sayings of Imam Ali, Letter no. 31. Qum, Iran: Ansariyan Publications, 1989, http://www. al-islam.org/nahj/ (accessed 18 Apr 2006).

8 Guyer P. Kant, Immanuel, part 9: The value of autonomy and the foundation of ethics. In: Craig ET, ed. The Routledge encyclopedia of philosophy. London: Routledge, 1998:177-200.

9 Kulayni M. Book 1: Kitab al-'Aql, v. 1. Hadith no. 23. Al-Usul al-Kafi [Translated by SMH Rizvi]. Tehran: WOFIS, 1978.

10 Shakir MH. Holy Qur'an (Al-Qur'an al-Hakim), Elmhurst, NY Tahrike Tarsile Qur'an, 1983. http://www.hti.umich.edu/k/koran/NB /accessed 18 Apr 2006)

11 Hurr al-'Amili M. Book 74: Istihabab al-sabr 'ala balaa', Vol. 3. Hadith no. 3566. Wasa'il al-Shi'ah. Qum: Al-Mu'assasah Aal al-Bayt, 1989:257.

12 Majlisi MB. Vol. 77. Hadith no. 1. Bihar al-Anwar. Beirut: Mu'assasah al-Wafa', 1984:233

13 Majlisi, MB. Book 9: Makarim akhlaqihi wa sirahi wa sunnahi.Vol. 16. Hadith no. 142. Bihar al-Anwar. Beirut: Mu'assasah al-Wafa', 1984:287.

14 Beauchamp TL, Childress JF, eds. Respect for autonomy. In: Principles of biomedical ethics. New York: Oxford University Press, 2001:60.

15 Hewson B. Reproductive autonomy and the ethics of abortion. J Med Ethics 2001;27(Suppl 2):ii10-4.

16 Wyatt J. Medical paternalism and the fetus. J Med Ethics 2001;27(Suppl 2):ii15-20.

17 Ross MG, Ervin MG, Novak D. Placental and fetal physiology. In Gabbe SG Niebyl JR, et al, eds. Obstetrics: normal and problem pregnancies. New York: Churchill Livingstone, 2002:37-54.

18 Roe v Wade. United States Supreme Court Reports. United States Supreme Court 1973:410:959.

19 Griswold v Connecticut. United States Supreme Court Reports. United States Supreme Court 1965;381:479

20 Singer P. Practical ethics. Cambridge: Cambridge University Press, 1979:122-3.

21 Kulayni M. Bab al-Bad'a al-insan wa taqallabuhu fi batn ummahi, Vol. 6. Hadith no. 3. al-Usul al-Kafi. Tehran: Dar al-Kutub al-Islamiyyah, 1978:13.

22 Hedayat K, Shooshtarizadeh P, Raza M. Therapeutic abortion in Islam: contemporary views of Muslim Shiite scholars and impact of recent Iranian legislation. J Med Ethics. In press.

23 Rohani-Aliabadi M, Noghani F. Asrar-e Bimaran. Ahkam-e Islami. Tehran: Moassasseh Farhangi Entesharat-e Taymurzadeh, 1996:66-9.

24 Francione GL. Federal animal welfare act. Animals, property, and the law: ethics and action. Philadelphia, Temple University Press, 1995: 185-207, http:// animal-law.org/statutes/index.html for state statutes in the United States (accessed 18 Apr 2006).

25 Francione GL. Abortion and animal rights: are they comparable issues? Reutgers University School of Law online library of animal law 2002. http://animal-law. org/commentaries/ap18.htm.

26 World Medical Association. Declaration of Ottawa on the rights of the child. 1998. http://www.wma.net/e/policy/c4.htm (accessed 3 Mar 2006).

27 Anon. Convention for Protection of Human Rights and Dignity of the Human Being with Regard to the Application of Biology and Biomedicine: convention of Human Rights and Biomedicine. Kennedy Inst Ethics J 1997;7:277-90.

28 Fuller J. AIDS prevention: a challenge to the Catholic moral tradition. America 1996;175:13-21

29 Niknam MH, Golmakani MM, Hedayat KM. Islamic ethics of organ transplantation. Med Sci Monitor 2005; 11:RA 105-9. 